\title{
Educational Approaches to the Military Journalists Training (The Case of Russia)
}

\author{
Sergey G. Korkonosenko ${ }^{1}$ and Zalina F. Khubetcova ${ }^{1, *}$ \\ ${ }_{1}^{1}$ Saint Petersburg State University, 7-9, Universitetskaya nab., Saint Petersburg, 199034, Russia \\ *Corresponding author
}

Keywords: Journalism Education, Military Journalist, Thematic Specialization, University.

\begin{abstract}
The article touches upon the issue how valuable a special education is for professional journalists. In this context, the authors consider organizational and methodological approaches to the military journalists' training. The purpose of the article is to compare different approaches formed in other countries, and to assess the practice of their application. The authors use the method of analytical description of educational experience; on this basis, they identify the strengths, weaknesses, opportunities, and threads of each approach (the SWOT analysis methodology). The results give reasons to conclude that, firstly, the optimal system of military journalists' training today is in the process of formation, and secondly, it will combine different approaches and models, which are largely due to national traditions in journalism and higher education.
\end{abstract}

\section{Introduction}

Journalism is one of the so-called open professions that do not require licenses, diplomas or other official certificates. In the editorial offices, the certified reporters seat side by side with colleagues who have got education in other branches of knowledge. There are even media organizations where there is no employee with specialized education. Since the foundation of the world's first journalistic schools and relevant university departments, there has been much debate about whether a journalist should be trained at university and whether he needs a specific educational basis. It is not by chance that such issues from time to time are being hotly discussed both in the editorial offices and in universities, in particular among students. But the initiators of these discussions do not always clearly imagine that the "introduction" of journalism to universities was not due to someone's arbitrariness, but as a result of a rather long evolution of the training for the press system $[1,2]$. Through polemics, experiments and the development of teaching methods, society has come to the existing education system, which, of course, also does not remain unchanged.

In the 21 st century, the most intensive search began for a model of training in journalism, which would meet the needs of society, the requirements of the media market, and the personal interests of graduates. Discussions on the role of universities in improving the quality of journalism in the national and ethnic context are becoming more and more active [3, 4, 5]. While technologies radically transformed journalism methods and skills, a new discourse on how in convergent media, digital skills should be combined with media workers' creative abilities has gained popularity $[6,7]$; 
and also the debate intensified on the appropriateness of the journalism education orientation on a specific thematic specialization [8].

In these discussions, we support the views of those who advocate the professional training of journalists in the frame of higher education, focused on specific topics. Such thematic specializations exist, within which there is no place for non-professionals. It is not even that the journalist's incompetence may have negative consequences for the audience (as, for example, while covering the health and medicine topics), but that a particular industry may belong to the sphere of strategic interests of the state and be regulated in a special way. The military field is one of such complex thematic specializations. "Embedded civilian journalists, though vital storytellers are at a disadvantage when it comes to accessing inside information and, more importantly, understanding the troops' perspectives. Journalists within the military are better able to give voice to the daily lives of their brothers- and sisters-in-arms, delivering the difficult facts" [9]. In the last decades, the volume of information of a military-political nature has been constantly growing. For example, in Russia, special analytical columns headings appeared in the press, on radio and television to cover the policy in the military sphere; the military-political theme becomes an integral part of the daily news flow.

In the article, we aim to consider approaches to the educational training of military journalists, as well as the experience of practical implementation of these approaches.

\section{Results and Discussion}

\subsection{Training of Military Journalists for the Ministry of Defense}

In the USSR, there was a well-arranged system of higher education for military journalists; Lvov Higher Military-Political School was the leading organization. But after the collapse of the Soviet Union, the reproduction of professional journalists to cover military and political topics stopped. Only at the end of the 2000s attempts to build a new model of training journalists started. It was necessary to take into account not only the previous national experience, but also various options from foreign practice. For example, in Canada, a scholarship exists for students to attend a nine-day certificate course on military journalism. The course includes a combination of media-military theory in a classroom setting, coupled with field visits to armed forces regular force and reserve units. Requirements for pre-training of students are limited - at minimum - the third year of a university journalism degree [10]. Meanwhile, in the USA, the training program of radio and TV journalists for the Air Force requires high school diploma or GED with 15 college credits, knowledge of basic communication theory, completion of 8.5 weeks of basic military training, etc. [11]. In Russia, the Ministry of Defense made choice in favor of university-level training. On its initiative, an educational experiment was launched at several universities, and special journalistic personnel for the armed forces began to be trained. Thus, at the Voronezh State University, the Faculty of Journalism has organized education on two profiles for the military sphere: "Public relations" and "Information support of activities" (2006). Later, the State Educational Standard on the specialty 56.05.05 "Military journalism" (with five years teaching period) was developed, and specialized training of journalists for military agencies started. The first admission to the new specialty was in 2016 at the Voronezh State University; in 2017, the Military University of the Ministry of Defense joined the experimental teaching of military journalists.

In Voronezh, the basic structural units are the Faculty of Journalism and the Military training center. The program for military journalists has few characteristic features: weekly, one school day students are busy with military affairs; on ordinary days, along with traditional journalistic disciplines, they study a number of special courses; after the 4th course, they come to two-week military training camp, where future officers take the oath, and on the 5th course they get a monthly 
internship in a future position. Military journalists leave the University with the Lieutenant rank. As military personnel, they have the status of non-combatants, that is, members of a special unit of the armed forces, whose functions are limited to supporting and serving the combat activities; and then, they have the right to use weapons only for self-defense.

The model of training journalists for defense agencies at classical universities, as well as at specialized military universities, has undeniable advantages. Firstly, the methods of training allow forming personal competencies of future journalists, which are understood as value orientation, civic consciousness, self-regulation, and self-improvement [12]. For the journalist who works with strategic information, this set of professional competencies is almost the main one.

Secondly, the correlation of the training system with the conditions of real army service not only disciplines students, but also contributes to their adaptation to the profession. Remarkably, the majority of graduates can find a job directly in the military media system. Compared with the Soviet era, the number of military media has decreased significantly, but specialized media open a sufficient number of vacancies in the present labor market. The Russian Ministry of Defense publishes more than 20 periodicals; the Air Force, Navy and Railway Forces have their own newspapers and magazines, plus numerous resources on the Internet were set up [13]. The complex of audiovisual media is developing vigorously. The main role belongs to the "Zvezda" media holding (2005), which combines in itself the Federal TV channel of the same name, "Radio Zvezda" channel and tvzvezda.ru and radiozvezda.ru information portals. The TV channel "Zvezda" is included in the Russian public multiplex and is one of the leaders of TV viewing among the male audience 55+ [14].

Thirdly, a systematic and in-depth study of military field, along with the development of reporting technologies and methods of creative working in journalism - this is exactly the set of conditions that are necessary for the competent professional's growing. Experience shows, "that untrained journalists are often sent to report on hostilities, showing great independence but at the risk of their personal safety ... [There is] a concern at the presence in operational theatres of independent journalists of uncertain status, given great freedom but little protection by their editorial managers" [15]. The model for training military journalists described above aims to fill gaps in knowledge and skills.

It is not yet possible to assess the effectiveness of the new (post-Soviet) system of training journalists for defense agencies, as none of the two universities has yet had graduates on the "Military journalism" specialty. One can only assume that a new cohort of media professionals in coverage of military topics will be able to participate in solving problems of national importance, primarily in the area of strengthening the country's defense and improving the armed forces.

\subsection{Training of Military Analysts for Universal Media}

One of the main disadvantages of training military journalists for defense agencies is that the professional activities of graduates are focused on the interests of armed forces; to a lesser extent, it contributes to realization of the most important principle of modern Russian military policy - the principle of civil control over the development and implementation of military policy. It is characteristic that large associations of military journalists consider their priority task to provide the interaction of the army with the population. So, "Military Reporters and Editors" (USA) formulates its own mission as follows: "The Association exists to advance public understanding of the military, national security and homeland defense..." [16].

If journalist is involved in the military system, it would be difficult for him to distance from corporate interests, to focus on a critical analysis of the military administration and the country's leadership actions, and to assess the effectiveness of military expenses. That is why there is no less demand for training journalists-analysts at civilian universities who are able not only to carry out 
qualitative military reporting, but also to understand a wide range of military and political problems. In the $2000 \mathrm{~s}$, the attempts were made to train journalists with a professional skills in political analysis at some Russian classical universities, both at the bachelor level (for example, the bachelor's program in political journalism was established at the Journalism Faculty of Lomonosov Moscow State University) and at the specialist level (for example, thematic specialization in political journalism existed at the Journalism Faculty of St. Petersburg State University). However, to date, the model of political analysts training at the level of academic master's degree has become more popular. Thus, the master's program in political journalism has been implemented at St. Petersburg State University for more than ten years. In this form of training, military-political subjects constitute a special thematic block. This thematic block is presented in the curriculum of the master's degree in journalism as separate training courses (journalism in hot spots, militaryhistorical journalism, journalism in information wars) and thematic modules within the humanitarian and professional disciplines (psychology of journalism, information security, international humanitarian law in the media, the history of Russian journalism, media law in journalism, and professional ethics in journalism).

Too wide range of political phenomena, which the student gets acquainted in the frame of the master's program, does not allow him to form in-depth special knowledge in the military sphere. Therefore, graduates of civilian universities cannot compete with professionals who came to military journalism from the military sphere directly. That is, the graduates need to undergo additional internship in practical military journalism. It is noteworthy that among the leading Russian television war correspondents only a few persons are certified journalists. The master's degree in political journalism could attract talented people from the military sphere who need specialized professional journalistic knowledge and skills. Perhaps this is one of the promising approaches to forming high level experts in the complex professional field.

The choice of theoretical and pedagogical approaches in the field has international meaning. The lack of qualified experts in military journalism is an urgent problem for other republics from the former Soviet Union, which, along with Russia, inherited traditions of the Soviet journalistic education. In some of them, the need for professionals of this kind was recognized at the government level. In particular, since 2019, the University of Journalism and Mass Communications of Uzbekistan will start training military journalists, and a Memorandum of cooperation with national Defense Ministry was signed for this purpose. Students will have to master a four-year undergraduate program, after which future military journalists will pass a fourmonth refresher course. According to the creators of this educational project, the new personnel reserve "will display military topics in the media at a higher quality level, will increase the volume of analytical materials on this topic, and will provide more professional coverage of military life in audiovisual and online media" [17].

\section{Conclusion}

The renovations in training military competent journalists should become a timely and adequate response of the Russian education system to the needs of society, the state and the media. Over the next few years, it will be possible to assess the effectiveness of approaches to the training of journalists with military specialization and to adjust educational schemes that did not meet expectations. Today, one of the most pressing problems is the continuity of pedagogical traditions, because the highly qualified teaching staff, which has got a military journalism education in the Soviet period, is in the pre-retirement or retirement age. Thus, the training of military journalists gets one more aspect, namely the formation of pedagogical resources, of sufficient quantity and quality. 


\section{References}

[1] Z.F. Khubetsova, Russian academic schools of journalism as a part of the global research and educational process. Vestnik of Saint Petersburg University. Language and Literature, 2018, 15 (2): $312-326$.

[2] I.A. Fateeva, K.P. Novicky: The origins of professional media education. Bulletin of Chelyabinsk State University, 2007, 11: 102-109.

[3] I.N. Abusharif, Framing Journalism Education. The Journal of General Education, 2014, 63(2-3): 198-204.

[4] R.S. Goodman, E. Steyn (Eds.), Global journalism education in the $21^{\text {st }}$ century: Challenges and innovations. Austin: Knight Center for Journalism in the Americas, University of Texas at Austin, 2017.

[5] S.G. Korkonosenko, Methods of teaching journalism as academic course in higher school. Media Education (Mediaobrazovanie), 2018, 58(3): 80-88.

[6] C. Berret, C. Phillips, Teaching data and computational journalism. New York: Columbia Journalism School, 2016.

[7] Z.F. Khubetsova, S.G. Korkonosenko, I.N. Blokhin, Journalistic education: Conceptualization and media competences. Mediterranean Journal of Social Sciences, 2015, 6(3 S3): 107-114.

[8] D. Marchetti, Subfields of specialized journalism // R. Benson, E. Neveu (Eds), Bourdieu and the Journalistic Field. Cambridge: Polity Press, 2005: 85-112.

[9] A. Luckwaldt, How to become a journalist in the military. The Balance Careers, 2019, January 29. https://www.thebalancecareers.com/overview-of-journalism-careers-in-the-military2356495.

[10] Military journalism. Centre for Military, Security and Strategic Studies. https://cmss.ucalgary.ca/journalism.

[11] Broadcast journalist. https://www.airforce.com/careers/detail/broadcast-journalist.

[12] L.S. Makarova, Competence-based approach in the modern journalism education. Vestnik of Lobachevsky University of Nizhni Novgorod, 2014, 2(2): 452-453.

[13] Information services in the Russian Armed Forces. The Ministry of Defense of the Russian Federation: Media. https://sc.mil.ru/social/media.htm.

[14] About the company. https://tvzvezda.ru/about/.

[15] F. Daucé, Military journalists and war correspondents. From the USSR to Russia: Subjectivity under fire. The Journal of Power Institutions in Post-Soviet Societies, 2014, 16. http://journals.openedition.org/pipss/4121.

[16] MRE Constitution. Military Reporters and Editors Association. http://militaryreporters.org/about/mre-constitution/.

[17] Uzbekistan will begin to educate military journalists. Fergana news, 2019, March 12. https://fergana.agency/news/105833/. 